\title{
o2. Akademik tartışma modelinin öğrencilerin eleştirel düşünme eğilimine etkisi
}

\section{Faruk KAYMAN' \\ Erkan AYDIN2}

APA: Kayman, F.; Aydın, E. (2021). Akademik tartışma modelinin öğrencilerin eleştirel düşünme eğilimine etkisi. RumeliDE Dil ve Edebiyat Araştırmaları Dergisi, (24), 10-20. DOI: 10.29000/rumelide.990055.

$\ddot{\mathbf{O} z}$

Eleştirel düşünme, hayatın her alanında farklı bir bakış açısı geliştirebilmek, fikirleri sorgulayabilmek, bilgileri ve düşünceleri ayırt edebilmek için kullanılan çok önemli bir beceridir. Bu becerinin geliştirilmesi amacıyla şu ana kadar birçok farklı yol ve yöntem denenmiştir. Son zamanlarda öğrencilerin eleştirel düşünme, sorgulama, eleştirel konuşma gibi birçok becerisine katkısı olduğu düşünülen akademik tartışma modeli adında (accountable talk) bir model ortaya konulmuştur. Bu bağlamda, araştırmada akademik tartışma modelinin ortaokul 8. sınıf öğrencilerinin eleştirel düşünme eğilimlerine etkisinin olup olmadığını tespit etmek amaçlanmıştır. Araştırma, nicel araştırma desenlerinden ön-test ve son-test kontrol gruplu yarı-deneysel desenle tasarlanmıştır. Araştırmanın uygulama kısmı Van ili Tuşba ilçesine bağlı Hasan Ali Yücel Ortaokulunda yapılmıştır. Araştırmanın çalışma grubunu, yansız atama yoluyla seçilen ve bir deney $(\mathrm{N}=21)$ bir de kontrol $(\mathrm{N}=19)$ grubundan oluşan toplam 40 öğrenciden oluşmaktadır. Araştırmada veri toplama aracı olarak Giancarlo ve Facione tarafından geliştirilen ve Özdemir tarafından Türkçeye uyarlanan "Kaliforniya Zihinsel Güdülenme Ölçeği (Eleştirel Düşünme Eğilimi Ölçeği)" kullanılmıştır. Verilerinin analizinde, "SPSS 20" istatistik paket programına başvurularak gruplar arasındaki farkı anlamak için ilişkisiz t-testi; grupların kendi içindeki farkı anlamak için ilişkili t-testi kullanılmıştır. Araştırma sonucunda, akademik tartışma modelinin uygulandığı deney grubu öğrencilerinin eleştirel düşünme eğilimlerinde, mevcut programla ders işleyen kontrol grubu öğrencilerine göre önemli bir artış olduğu ve anlamlı bir farklılı̆̆ın olduğu tespit edilmiştir.

Anahtar kelimeler: Akademik tartışma, ortaokul öğrencileri, eleştirel düşünme eğilimi

\section{The effect of accountable talk model on students' critical thinking disposition}

\begin{abstract}
Critical thinking is a very important skill that is used to develop a different perspective in all areas of life, to question ideas, to distinguish information and thoughts. In order to develop this skill, many different ways and methods have been tried so far. Recently, a model named academic discussion model (accountable talk) has been introduced, which is thought to contribute to many skills of students such as critical thinking, questioning, and critical speaking. In this context, it was aimed to determine whether the academic discussion model had an effect on the 8th grade students' critical thinking dispositions. The research was designed with a quantitative quantitative research design, pre-test and post-test control group quasi-experimental design. The application part of the study was
\end{abstract}

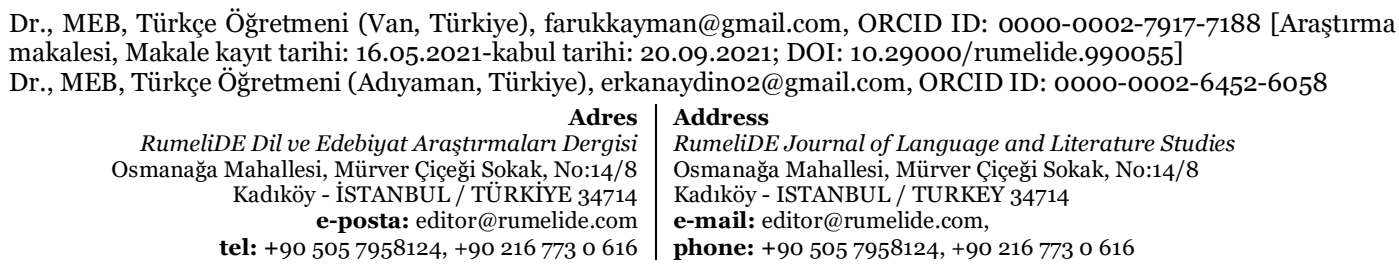


carried out in Hasan Ali Yücel Secondary School in the Tusba district of Van. The study group of the research consists of a total of 40 students, who are chosen through unbiased assignment, consisting of an experiment $(\mathrm{N}=21)$ and a control $(\mathrm{N}=19)$ group. The "California Mental Motivation Scale (Critical Thinking Disposition Scale)" developed by Giancarlo and Facione and adapted into Turkish by Özdemir was used as a data collection tool in the study. In the analysis of the data, using the "SPSS 20" statistical package program, the unrelated t-test to understand the difference between the groups; The correlated t-test was used to understand the difference within the groups. As a result of the research, it was determined that there was a significant increase and a significant difference in the critical thinking dispositions of the experimental group students in which the academic discussion model was applied compared to the control group students who were teaching with the current program.

Keywords: Accountable talk, middle school students, critical thinking disposition

\section{Giriş}

İnsan, düşünme yetisi sayesinde diğer varlıklardan ayrılmakta ve yaşadığı çevreyi tanıyarak ona uyum sağlayabilmektedir. Günlük hayatta meydana gelen olaylar karşısında sağllklı tepkiler verebilmek, bireysel ve toplumsal faydayı gözeterek hareket etmek ve hayatı kolaylaştıracak adımlar atmak yine düşünme becerisi sayesinde mümkün olabilmektedir.

Düşünme kavramı literatürde çeşitli şekillerde tanımlanmaktadır. Cüceloğlu'na göre (1999) düşünme, kişinin içinde bulunduğu durumu anlayabilmesi için aktif, amaca yönelik ve örgütlü bir şekilde gerçekleştirdiği zihinsel faaliyete verilen addır. Yıldırım (2003) ise "kavramlar ve olaylar arasında anlamlı bağlantılar kurma ve sonuçlar çıkarma” şeklinde tarif etmektedir. İnsan hayatında önemli bir yere sahip olan düşünme becerisi, ilk yllarda aile ve sosyal çevrenin etkisiyle şekillenmekte, çocuğun okula başlamasıyla birlikte uygulanan öğretim programlarına paralel olarak üst düzey düşünme becerilerine doğru evrilebilmektedir.

Piaget'e göre, eğitim kurumlarında öğrencilere verilen eğitimle geçmişte elde edilen kazanımların ve gelişmelerin bir adım ötesine geçmek, geçmişi tekrar eden bireylerden ziyade sürekli yeni şeyler üretmeye çalışan insanlar yetiştirmek amaçlanmalıdır. Dolayısıyla okullarda verilen eğitimden beklenen, verilen bilgiyi olduğu gibi alan, bunu sorgulamadan kabul eden öğrenciler yetiştirmek yerine eleştirel düşünebilen, bilgiyi zihninde analiz edip sorgulayabilen bireyler yetiştirmek (Fisher, 2005) olduğu söylenebilir.

Üst düzey düşünme becerilerinden biri olan eleştirel düşünmeyi; düşüncelerin, iddiaların veya bilgilerin kaynaklarını bularak ve bunların tutarlı ve akılcı olup olmadığını göz önünde bulundurarak onları düzenleme, diğer düşünce ve bilgilerle ilişkilendirme, bunun yanında farklı kaynakları dikkate alma ve onların anlamlarını değerlendirme süreci (Andolina, 2002) olarak tanımlamak mümkündür. Eleştirel düşünme sayesinde birey karşılaştığı olaylar, durumlar veya düşüncelerdeki tutarlılığı fark edebilir; çıkarsamaları ve bunların nedenlerini değerlendirebilir; varsayımları, iddiaları ve fikirleri ayırt edebilir; öne sürülen kanıtlardaki eksiklikleri veya açiklamalardaki belirsizlikleri görebilir ve elde edilen sonuçların uygunluğunu ölçebilir (Özden, 2006). Öğrencilere bu becerilerin kazandırılabilmesi için sağllklı, etkili ve modern bir öğretim sürecine ihtiyaç duyulmaktadır. Öğrenciyi merkeze alan, onun bilgiye ulaşmasına, onu üretmesine katkı sağlayan, onu analitik ve eleştirel düşünmeye yönlendiren,

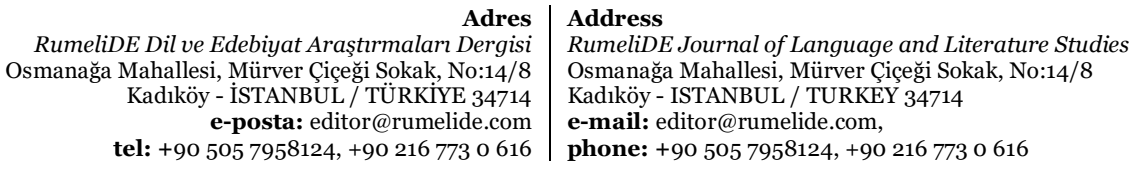


kendine olan güvenini arttıran çeşitli etkinliklerin yapılması, yöntem, teknik ve modellerin kullanılması öğrencinin üst düzey düşünme becerilerini kazanmasında büyük önem taşımaktadır.

Yapılandırmacı yaklaşıma uygun, öğrencinin aktif katılımını amaçlayan, öne süreceği düşünceleri doğru ve kanıtlara dayanarak sunmasını önemseyen bir konuşma/tartışma modeli olan Akademik tartışma modeli (accountable talk); Sara Michaels, Mary Catherine O'Connor ve Lauren B. Resnick tarafindan oluşturulmuştur. Türkçeye "sorumlu/açıklayıcı/açıklanabilir" konuşma olarak çevrilen bu model, akademik bir konuşmayı yansıtması bakımında Özçetin (2019) tarafından akademik tartışma modeli olarak adlandırılmıştır.

Akademik tartışma, öğrencilerin bir konu hakkında anladıklarını dile getirme ve sınıf içinde rahat bir şekilde ifade etme noktasında onlara güvenli bir ortam sunar. Öğrenciler tartışılan konu hakkında düşüncelerini aktarırlar, farklı görüşler ortaya atarak tartışırlar. Yapılan bu konuşmalar ve tartışmalar neticesinde geniş bir bilgi birikimi oluşur (Howell, Thomas \& Ardasheva, 2011).

Akademik tartışmada öğretmenlerin öğrencinin tartışmaya katılımına rehberlik etmesi beklenir. Öğretmenler, uygun tartışma biçimlerini belirledikten sonra tartışmayı yönlendirerek sinıflarında akademik tartışma kurallarının ve öğrencilerin bu konudaki becerilerinin oluşmasını sağlarlar. Örneğin, öğretmenler tartışma esnasında öğrencilerden tartışılan konuyla ilgili açılama yapmasını isteyebilir, doğru bilgi sunması için öğrencilere baskı yapabilir, onlardan fikirlerini ve önerilerini gerekçelendirmesini isteyebilir, ortaya atılan iddialar için kanıt talep edebilir veya öğrencilerin ifadelerini yorumlayabilir ve gözden geçirebilir. Sınıf içinde oluşturulacak akademik tartışma kuralları akademik amaçlar doğrultusunda öğretmenler ve öğrenciler tarafından ortaklaşa inşa edilir. Sınıf içinde yapılacak akademik tartışma sınıftaki bütün öğrencilerin katıldığı sınıf tartışması, küçük grup çalışması, akran veya öğretmen sunumları gibi çeşitli biçimlerde olabilir. Ancak hangi biçim kullanılırsa kullanılsın tartışmada, öğrenen topluluğa (öğrencilere) karşı sorumluluk, konu için uygun olan bilgi ve kanıt standartlarına karşı sorumluluk ve genel kabul görmüş akıl yürütme standartlarına karşı sorumluluk aşamalarına uyulmalıdır. Bu sorumluluk aşamaları, öğrencilerin ve öğretmenin konuşmalarında görülmeli, sınıf kuralları ve yinelenen faaliyetlerin yanı sıra dikkatlice tasarlanmış görevlerle desteklenmelidir. Akademik tartışma, sadece en iyi ve en zeki öğrencilerle veya özel öğrenci gruplarıyla değil, tüm öğrencilerle yapılabilen bir tartışmadır. Bunun yanında tüm sınıf seviyelerinde ve tüm konu alanlarında akademik tartışma modeli kullanılabilir (Michaels, O’Connor, Hall \& Resnick, 2010; Affolter, 2020).

Akademik tartışmaya başlamadan önce öğrencilere bazı kuralların benimsetilmesi gerekmektedir. Buna göre; öğrenciler tartışma esnasında sürekli birbirleriyle göz teması kurmalı, birbirlerinin sözünü kesmemeli, çeşitli kaynaklardan alıntı yaparak konuşmalı, parmak kaldırmadan uygun zamanda söze girmeli, tartışılan konunun dışına çıkmamalı, görüşlerini gerekçelendirerek sunmalı, herkesin duyabileceği uygun bir ses tonuyla konuşmalı, birbirlerinin görüşlerine saygı duymalı ve açı kaynaklardan alıntı yapmalıdırlar (Özçetin, 2019).

Akademik tartışma modelinin üç aşaması bulunmaktadır. Bunlar; öğrenen topluluğa (öğrencilere) karşı sorumluluk, doğru bilgiye karşı sorumluluk ve etkili/derinlemesine düşünmeye karşı sorumluluk aşamalarıdır. Akademik tartışmanın planlanması ve uygulanması aşamalarında öğretmenin hem kendisine hem de öğrencilere doğru sorular sorabilmesi ve etkili uygulamalar yapabilmesi önemli görülmektedir. Bu tartışmayla birlikte öğrencilerin akademik bir dil kullanmaları, sağlıklı, tutarlı ve

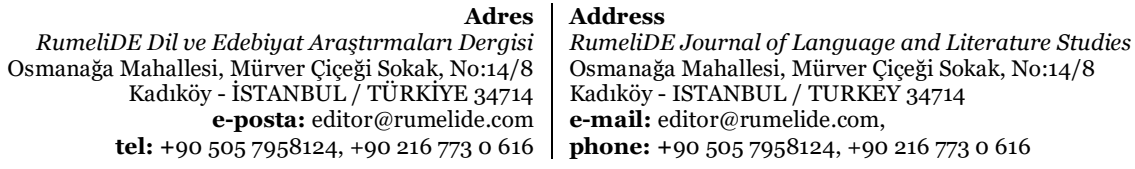


doğru kanıtlar sunmaları, öğretmenin rehberliğinde yeni bilgiler üretmeleri, bilgiler ve düşünceler arasında farklı bağlantılar kurmaları beklenmektedir.

İlgili literatür incelendiğinde eleştirel düşünme üzerine yapılan çok sayıda çalışma olduğu görülmektedir. Bu çalışmaların bir kısmının eleştirel düşünme becerisine (Özdemir, 2005; Akar, 2007; Bağcı ve Şahbaz, 2012; Ocak ve Kutlu Kalender, 2017; Özcan, 2017; Köksal ve Çöğmen, 2018; Mete, 2021) yönelik olduğu görülmektedir. Eleştirel düşünme eğilimi üzerine yapılan çalışmaların ise öğretmenleri (Korkmaz, 2009; Polat, 2017; Püsküllüoğlu ve Altınkurt, 2018), öğretmen adaylarını (Aybek, 2007; Durukan ve Maden, 2010; Emir, 2012; Can ve Kaymakçı, 2015), lise öğrencilerini (Akbıyı ve Seferoğlu, 2006; Korkmaz ve Yeşil, 2009; Demir ve Aybek, 2014) ve ortaokul öğrencilerini (Yıldırım ve Şensoy, 2011; Ersoy ve Başer, 2012; Bayındır, 2015; Bulut, 2018; Kurga, 2021) kapsadığı görülmüştür.

Günümüz eğitim kurumlarında eleştirel düşünebilen, yaparak yaşayarak öğrenen, tüm etkinliklerde aktif rol alabilen, bilgiyi üreten bireylerin yetiştirilmesi hedeflenmektedir. Öğrencilerde bu eğilimlerin oluşması, onlara bu davranışların ve becerilerin kazandırılması yapılandırmacı yaklaşıma uygun model, yöntem ve tekniklerin kullanılmasıyla mümkün olabilmektedir. Bu çalışma bu amaçla yapılmış ve çalışmada akademik tartışma modelinin 8. sınıf öğrencilerinin eleştirel düşünme eğilimlerine etkisi tespit edilmeye çalışılmıştır. Daha önce akademik tartışma modelinin öğrencilerin eleştirel düşünme eğilimlerine etkisini ele alan herhangi bir çalışmaya rastlanmamıştır. Bu nedenle yapılan bu çalışmanın literatüre katkı sağlayacağı düşünülmektedir.

\section{Araştırmanın amacı}

$\mathrm{Bu}$ araştırmada, akademik tartışma modelinin ortaokul 8. sınıf öğrencilerinin eleştirel düşünme eğilimlerine etkisini incelemek amaçlanmıştır. Bu amaç doğrultusunda aşağıdaki sorulara yanıt aranmıştır.

1. Uygulama öncesi deney ve kontrol grubu öğrencilerinin eleştirel düşünme eğilimlerinde istatistiksel olarak anlamlı bir farklılık bulunmakta mıdır?

2. Deney grubu öğrencilerinin uygulama öncesi ile uygulama sonrasında eleştirel düşünme eğilimlerinde istatistiksel olarak anlamlı bir farklılık bulunmakta mıdır?

3. Kontrol grubu öğrencilerinin uygulama öncesi ile uygulama sonrasında eleştirel düşünme eğilimlerinde istatistiksel olarak anlamlı bir farklılık bulunmakta mıdır?

4. Uygulama sonrası deney ve kontrol grubu öğrencilerinin eleştirel düşünme eğilimlerinde istatistiksel olarak anlamlı bir farklılık bulunmakta mıdır?

\section{Yöntem}

Araştırma, nicel araştırma desenlerinden ön-test ve son-test kontrol gruplu yarı-deneysel desenle tasarlanmıştır. Araştırmacı bu desende, bir işlem yaparken deney grubuna müdahalede bulunurken kontrol grubuna bulunmaz ve grupların işlem sonucunda aldıkları puanları belirleyerek değerlendirmeler yapar. Ayrıca bu desende denekler, rastgele olmadan amaçlı bir şekilde seçilir (Creswell, 2017). Araştırmada, deney grubu öğrencileri akademik tartışma modeliyle ders işlerken kontrol grubu öğrencileri ise mevcut programla ders işlemiştir. Aşağıda bu uygulamaya yönelik şematik gösterim verilmiştir.

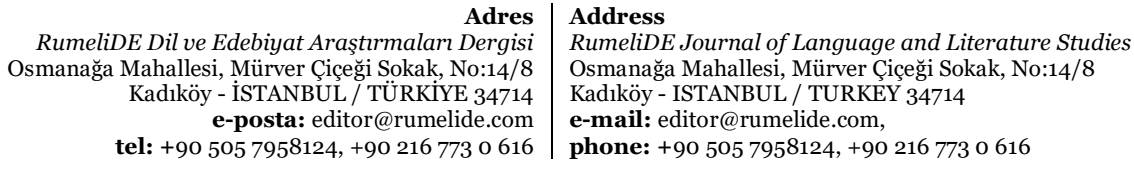




\begin{tabular}{llll}
\hline Grup & Ön-test & Uygulama & Son-test \\
\hline Deney & $\mathrm{O} 1 / 1$ & Akademik Tartışma Modeli & $\mathrm{S} 1 / 2$ \\
Kontrol & $\mathrm{O} 2 / 1$ & Mevcut Program & $\mathrm{S} 2 / 2$ \\
\hline
\end{tabular}

\section{Çalışma grubu}

Araştırmanın çalışma grubunu Van ili Tuşba ilçesine bağlı Hasan Ali Yücel Ortaokulunda öğrenim görmekte olan 8. sınıf öğrencileri oluşturmuştur. Çalışma grubunda yer alan bu öğrencilerden yansız atama yoluyla bir deney $(\mathrm{N}=21)$ bir de kontrol $(\mathrm{N}=19)$ grubu seçilmiş ve toplamda 40 öğrenci üzerinden uygulama yapılmıştır.

\section{Uygulama süreci}

Araştırmanın uygulama süreci 5 hafta sürmüş, öğrencilerle her bir haftada 4 ders saati olmak üzere toplamda 20 ders saati uygulama yapılmıştır. Buna göre;

- Birinci hafta: Araştırmacı tarafından deney ve kontrol grubu öğrencilerine Eleştirel Düşünme Ĕ̆ilimi Ölçeği uygulanmış, deney grubu öğrencilerine akademik tartışma modeli hakkında bilgi verilmiştir. (2 ders saati)

- Birinci hafta: 8. sınıf Türkçe ders kitabında yer alan "İnsanla Güzel” adlı metin, deney grubu tarafından akademik tartışma modeline uygun bir şekilde tartışılmıştır. (2 ders saati)

- İkinci hafta: 8. sınıf Türkçe ders kitabındaki “Dilimiz Kuşatma Altında” adlı metin deney grubu tarafından akademik tartışma modeline uygun bir şekilde tartışılmıştır. (2 ders saati)

- İkinci hafta: 8. sınıf Türkçe ders kitabındaki "Rüzgâr" adlı metin, deney grubundaki öğrenciler tarafından akademik tartışma modeline uygun bir şekilde tartışılmıştır. (2 ders saati)

- Ü̈çüncü hafta: 8. sınıf Türkçe ders kitabında yer alan "Gündelik Hayatımızda E-Hastalıklar" adlı metin deney grubu tarafından akademik tartışma modeli kullanılarak tartışılmıştır. (2 ders saati)

- Üçüncü hafta: 8. sınıf Türkçe ders kitabındaki "Kaldırımlar" adlı metin, deney grubundaki öğrenciler tarafından akademik tartışma modeline uygun bir şekilde tartışılmıştır. (2 ders saati)

- Dördüncü hafta: 8. sınıf Türkçe ders kitabındaki "Hava Kirliliği” adlı metin deney grubu tarafından akademik tartışma modeli kullanılarak tartışılmıştır. (2 ders saati)

- Dördüncü Hafta: 8. sinıf Türkçe ders kitabında yer alan "Yaşamaya Dair" adlı metin deney grubu öğrencileri tarafından akademik tartışma modeli kullanılarak tartışılmıştır. (2 ders saati)

- Beşinci hafta: 8. sınıf Türkçe ders kitabındaki "Yaşamaya Dair" adlı metin deney grubu tarafından akademik tartışma modeline uygun bir şekilde tartışılmıştır. (2 ders saati)

- Beşinci hafta: deney ve kontrol grubuna Eleştirel Düşünme Eğilimi Ölçeği son test olarak uygulanmıştır. (2 ders saati)

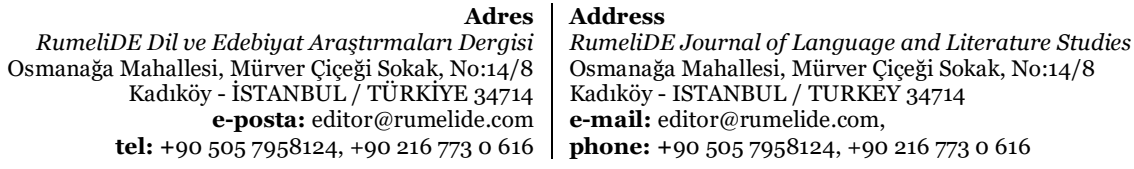




\section{Veri toplama aracı}

\section{Kaliforniya zihinsel güdülenme ölçeği (Eleştirel düşünme eğilimi ölçeği)}

Giancarlo ve Facione (2001) tarafından geliştirilen bu ölçek, 6-12. sınıf öğrencilerinin eleştirel düşünme eğilimlerini ölçmektedir. 4'lü likert tipinde hazırlanan ve Özdemir (2006) tarafından Türkçeye uyarlanan ölçek, 25 sorudan oluşmaktadır. Bu ölçek; eleştirel düşünme, düşünme, problem çözme ve muhakeme becerilerinin ölçülebileceği bağımsız bilişsel süreçleri kapsamaktadır. Ölçeğin "Öğrenme Yönelimi (1), Yaratıcı Problem Çözme (2), Zihinsel Odaklanma (3) ve Bilişsel Bütünlük (4)” şeklinde dört alt boyutu bulunmaktadır. Doğrulayıcı faktör analizi ile geçerliliği ortaya konulan bu ölçeğin güvenirliğini ölçmek amacıyla Cronbach Alpha güvenirlik katsayıları hesaplanarak 0,78 olarak bulunmuştur (Furat, 2009). Yapılan çalışmada, ölçeğin Cronbach-alfa güvenirlik katsayısı o,84 olarak hesaplanmıştır.

\section{Veri analizi}

Deney ve kontrol grubu öğrencilerinin ön-test ve son-testten aldıkları puanlara ilişkin normallik değerlerine bakılarak analizlerin hangi istatistik tekniği ile yapılmasına karar verilmiştir. Bu bağlamda her iki grubun eleştirel düşünme eğilimleri ölçeğinden aldıkları ön test ve son test puanlarının normallik değerini belirten çarpıklık ve basıklık değerleri Tablo 1'de gösterilmiştir.

Tablo 1. Grupların normallik değerlerini gösteren çarpıklık ve basıklık sonuçları

\begin{tabular}{llll}
\hline Gruplar & Test türü & Çarpılklk & Basılklk \\
\hline Deney Grubu & Ön test & -.112 & .059 \\
& Son test & -.119 & $-1,132$ \\
\hline \multirow{2}{*}{ Kontrol Grubu } & Ön test & -.179 & -.651 \\
& Son test & -.611 & -.225 \\
\hline
\end{tabular}

Yukarıdaki tabloya göre grupların ön-test ve son-testten elde ettikleri çarpıklık ve basıklık değerleri -1 ile +1 arasında olduğu görülmektedir. George ve Mallery’e (2019) göre çarpıklık ve basıklık değerlerinin -2 ile +2 arasında olması, ölçekten alınan puanların normal dağılımda olduğunu gösterir. Bu bakımdan grupların ön-test ve son-test puanlarının normal dağlım gösterdiği söylenebilir. Ayrıca normallik varsayımlarını gösteren bir diğer istatistik testi olan Shapiro-Wilk testinin sonuçlarına bakılmış ve bu sonuçlar Tablo 2'de gösterilmiştir.

Tablo 2. Grupların normallik değerlerini gösteren Shapiro-Wilk testi sonuçları

\begin{tabular}{lllll}
\hline Gruplar & Test türü & İstatistik & SD & Sig (p) \\
\hline \multirow{2}{*}{ Deney Grubu } & Ön test & .969 & 21 & .716 \\
& Son test & .943 & 21 & .247 \\
\hline \multirow{2}{*}{ Kontrol } & Ön test & .964 & 19 & .650 \\
Grubu & Son test & .948 & 19 & .371 \\
\hline
\end{tabular}

Tablo 2'ye göre grupların ön-test ve son-testten aldıkları değerlerin normallik varsayımlarını gösterdiği görülmektedir ( $\mathrm{p}>0.05)$.

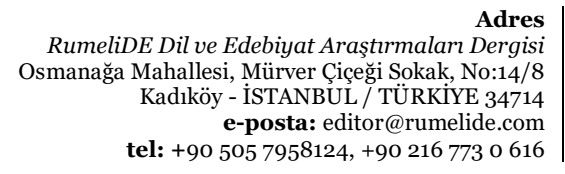

RumeliDE Dil ve Edebiyat Araştırmaları Dergisi Kadı̈̈y - İTTANBUL / TÜRKiYE tel: +90 505 7958124, +902167730616
Address

RumeliDE Journal of Language and Literature Studies

Osmanağa Mahallesi, Mürver Çiçeği Sokak, No:14/8

Kadıköy - ISTANBUL / TURKEY 34714

e-mail: editor@rumelide.com,

phone: +90 5057958124 , +90 2167730616 
Araştırmada, her iki grubun eleştirel düşünme eğilimleri ölçeğinin ön-test ve son-testinden aldıkları puanları karşılaştırılmıştır. İki grubun arasındaki anlamlılık düzeyini belirlemek için bağımsız (ilişkisiz) gruplar t-testine; iki grubun kendi içinde ön-test ve son-testler arasında anlamlılık düzeyini test etmek için ise bağımlı (ilişkili) gruplar t-testine başvurulmuştur.

\section{Bulgular}

Araştırmanın bu bölümünde, ölçek verilerinden elde edilen bulgular araştırma sorularına dayalı olarak tablolar halinde yorumlanmıştır.

Deney ve kontrol gruplarının eleştirel düşünme eğilimleri ön-test ortalamaları arasındaki farkı gösteren bağımsız (ilişkisiz) ölçümler t-testi sonuçları Tablo 3’te verilmiştir.

Tablo 3. Deney ve kontrol grubunun ön-test paunlarına ait bağımsız ölçümler t-testi sonuçları

\begin{tabular}{lllllll}
\hline Gruplar & $\mathbf{N}$ & $\overline{\mathbf{X}}$ & $\boldsymbol{S S}$ & $\boldsymbol{S D}$ & t & $\boldsymbol{p}$ \\
\hline Deney & 21 & 60,95 & 5,491 & 38 &,- 664 &, 511 \\
Kontrol & 19 & 62,21 & 6,494 & & & \\
\hline
\end{tabular}

Her iki grubun ölçekten aldıkları ön-test puanlarını belirlemek amacıyla bağımsız gruplar için t-testi yapılmıştır. Bu sonuçlara göre, deney grubu öğrencilerinin ön-test ortalama puanları $(X=60,95)$ ile kontrol grubu öğrencilerinin ön-test ortalama puanları $(X=62,21)$ arasında anlamlı bir farklılığın olmadığı görülmektedir $[\mathrm{t}(38)=-, 664(\mathrm{p}=, 511)]$. Bu sonuçlardan hareketle uygulama öncesinde her iki grubun eleştirel düşünme eğilimlerinin birbirine yakın olduğu söylenebilir.

Deney grubunun eleştirel düşünme eğilimi ölçeğinin ön-test ve son-test puanlarının dağılımına ilişkin bağımlı (ilişkili) ölçümler t-testi sonuçları Tablo 4’te verilmiştir.

Tablo 4. Deney grubu eleştirel düşünme eğilimi ölçeğinin ön-test ile son-test puanlarına ilişkin bağımlı ölçümler t-testi sonuçları

\begin{tabular}{llllllll}
\hline Gruplar & Ölçüm & $\mathbf{N}$ & $\overline{\mathbf{X}}$ & $\boldsymbol{S S}$ & $\boldsymbol{S D}$ & $\mathbf{t}$ & $\boldsymbol{p}^{*}$ \\
\hline \multirow{2}{*}{ Deney } & Ön-test & 21 & 60,95 & 5,491 & 20 & $-7,149$ & ,000 \\
& Son-test & 21 & 68,76 & 6,992 & & & \\
\hline
\end{tabular}

${ }^{*} \mathrm{p}<, 05$

Tablo 4'e göre, deney grubunun ön-test ortalama puanı $(X=60,95)$ ile son-test ortalama puanı $(X=$ $68,76)$ arasında anlamlı bir farklılığın olduğu görülmektedir $[(\mathrm{t}(20)=-7,194(\mathrm{p}=, 000)]$. Bu durum, deney grubunun akademik tartışma modeli uygulaması sonrasında eleştirel düşünme eğilimlerinin artı̆̆ını göstermektedir.

Kontrol grubunun eleştirel düşünme eğilimi ölçeğinin ön-test ve son-test puanlarının dağılımına ilişkin bağımlı (ilişkili) ölçümler t-testi sonuçları Tablo 5’te verilmiştir.

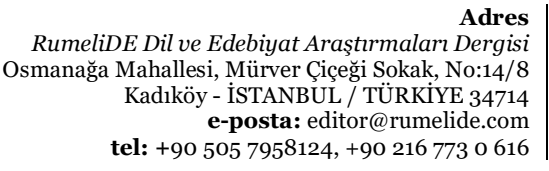

Adres
RumeliDE Dil ve Edebiyat Araştırmaları Dergisi in tel: +90 505 7958124, +902167730616
Address

RumeliDE Journal of Language and Literature Studies

Osmanağa Mahallesi, Mürver Çiçeği Sokak, No:14/8

Kadıköy - ISTANBUL / TURKEY 34714

e-mail: editor@rumelide.com,

phone: +90 5057958124 , +90 2167730616 
Tablo 5. Kontrol grubu eleştirel düşünme eğilimi ölçeğinin ön-test ile son-test puanlarına ilişkin bağımlı ölçümler t-testi sonuçları

\begin{tabular}{llllllll}
\hline Gruplar & Ölçüm & $\mathbf{N}$ & $\overline{\mathbf{X}}$ & $\boldsymbol{S S}$ & $\boldsymbol{S D}$ & $\mathbf{t}$ & $\boldsymbol{p}$ \\
\hline \multirow{2}{*}{ Kontrol } & Ön-test & 19 & 62,21 & 6,494 & 18 & $-1,365$ &, 189 \\
& Son-test & 19 & 62,95 & 6,696 & & & \\
\hline
\end{tabular}

Tablo 5'e göre mevcut programla ders işleyen kontrol grubu öğrencilerinin eleştirel düşünme eğilimi ölçeği ön-test ile son-test puanları arasında istatistiksel olarak anlamlı bir farkın olmadığını söylemek mümkündür $[\mathrm{t}(18)=-1,365(\mathrm{p}=, 189)]$.

Deney ve kontrol gruplarının eleştirel düşünme eğilimleri son-test ortalamaları arasındaki farkı gösteren bağımsız (ilişkisiz) ölçümler t-testi sonuçları Tablo 6’da gösterilmiştir.

Tablo 6. Deney ve kontrol grubunun son-test paunlarına ilişkin bağımsız ölçümler t-testi sonuçları

\begin{tabular}{llllclc}
\hline Gruplar & $\mathbf{N}$ & $\overline{\mathbf{x}}$ & $\boldsymbol{S S}$ & $\boldsymbol{S D}$ & $\mathbf{t}$ & $\boldsymbol{p}^{*}$ \\
\hline Deney & 21 & 68,76 & 6,992 & 38 & 2,680 &, 011 \\
Kontrol & 19 & 62,95 & 6,696 & & & \\
\hline
\end{tabular}

${ }^{*} \mathrm{p}<, 05$

Tablo 6 incelendiğinde, deney grubu öğrencilerinin eleştirel düşünme eğilimi ölçeği son-test ortalama puanları (X=68,76) ile kontrol grubu öğrencilerinin eleştirel düşünme eğilimi ölçeği son-test ortalama puanları $(X=62,95)$ arasında anlamlı bir farklılığın olduğu görülmektedir $[(\mathrm{t}(38)=2.68 \mathrm{o}(\mathrm{p}=.011)] . \mathrm{Bu}$ sonuçlardan hareketle akademik tartışma modelinin öğrencilerin eleştirel düşünme eğilimlerine etkisinin olduğunu söylemek mümkündür.

\section{Sonuç ve tartışma}

Toplumların gelişebilmesi ve sürdürülebilir bir ilerleme sağlayabilmesi için eğitimin kalitesinin büyük önem taşıdığı bilinmektedir. Eğitimin kalitesini arttırmak ise eğitim kurumlarında öğrenim gören öğrencileri farklı model, yöntem ve tekniklerle karşı karşıya getirmek ve işlenen derslerde üst düzey becerileri kazandırmaya yönelik etkinliklere bolca yer vermekle mümkün olabilmektedir.

Üst düzey becerilerden biri olan eleştirel düşünmenin öğrencilere yeterince kazandırılmadığı, bunun yanında bu beceriye yönelik algı düzeylerinin de beklenen seviyede olmadığı görülmektedir. Zira yapılan bazı çalışmalarda ortaokul, lise ve üniversitede öğrenim gören öğrencilerin eleştirel düşünmeye yönelik eğilimlerinin orta veya düşük düzeyde olduğu tespit edilmiştir (Ersoy ve Başer, 2012; Bayındır, 2015; Demir ve Aybek, 2014; Korkmaz ve Yeşil, 2009; Can ve Kaymakçı, 2015). Bu çalışmada bu durum göz önünde bulundurularak akademik tartışma modelinin ortaokul 8. sınıf öğrencilerinin eleştirel düşünme eğilimlerine etkisinin olup olmadığını tespit etmek amaçlanmıştır. Yapılan analiz sonucunda, akademik tartı̧̧ma modeliyle ders işleyen deney grubu öğrencilerinin mevcut programla ders işleyen kontrol grubu öğrencilerine göre eleştirel düşünme eğilimlerinde anlamlı bir fark gözlemlenmiştir. Bu bağlamda, akademik tartışma modelinin öğrencilerin eleştirel düşünme eğilimleri üzerinde etkili olduğu söylenebilir.

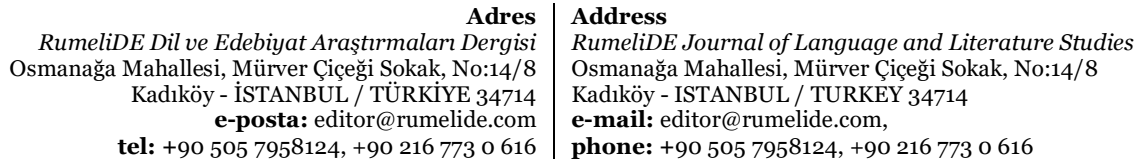


Literatürde farklı model, yöntem ve tekniklerin ortaokul öğrencilerinin eleştirel düşünme eğilimlerine etkisinin incelendiği sınırlı sayıda çalışmaya rastlanmıştır. Bulut (2018), aktif öğrenme modelinin 7. sınıf öğrencilerinin eleştirel düşünme eğilimlerine etkisini incelediği çalışmasında bu modelin öğrencilerin eleştirel düşünme eğilimini arttırdığı sonucuna ulaşmıştır. Yıldırım ve Şensoy (2011), yaptıkları çalışmada eleştirel düşünme becerilerini temel alan fen öğretiminin 7. sınıf öğrencilerinin eleştirel düşünme eğilimlerine etkisini incelemiş, çalışma sonunda bu öğretimin uygulandığı öğrencilerin eleştirel düşünme eğilimlerinde anlamlı bir artışın olduğunu tespit etmiştir. $\mathrm{Bu}$ çalışmalardan elde edilen sonuçlar araştırmanın sonuçlarıyla örtüşmektedir.

Farklı model, yöntem ve yaklaşımların ortaokul öğrencilerinin eleştirel düşünme eğilimlerine etkisini ölçen bu çalışmaların yanında, bunların, öğrencilerin eleştirel düşünme becerisine etkisini belirlemeye çalışan çalışmaların da olduğu görülmektedir (Evren, 2012; Aydede ve Kesercioğlu, 2010; Balta, 2011). Aktif öğrenme ve waldmann modelinin uygulandığı bu çalışmalarda bu modellerin ortaokul öğrencilerinin eleştirel düşünme becerilerini arttığı tespit edilmiştir.

Yapılan bu çalışmalarda da görüldüğü üzere yapılandırmacı yaklaşıma uygun, öğrenciyi aktif kılan, onun yaparak yaşayarak öğrenmesini sağlayan, kaygılarını gidermesine, kendisine güven duymasına ve üst düzey akıl yürütme becerilerini kazanmasına yardımcı olan model, yöntem ve teknikler öğrencilerin eleştirel düşünme eğilimlerini arttırmaktadır.

Sonuç olarak; öğretim programları hazırlanırken bu tespitlerin dikkate alınması, akademik tartışma modelinin de içinde olduğu çeşitli model ve yaklaşımların uygulandığı ders saatlerinin arttırılmasına yönelik çalışmaların yapılması ve bu yaklaşımın tüm sınıf seviyelerinde uygulanması büyük önem taşımaktadır. Bunun yanında, çalışmada bahsi geçen akademik tartışma modeli iyi düzeyde tecrübe ve donanım gerektiren bir model olduğu için öğretmenlerin bilgilenmeleri ve yeterli tecrübeye sahip olmaları için konu hakkında mesleki eğitimlerin düzenlenmesi ve uygulamalı çalışmaların yapılması gerekmektedir.

Araştırmacılara, akademik tartışma modelinin farklı kademelerdeki öğrencilerin eleştirel düşünme eğilimlerine ve becerilerine etkisini tespit etmeye yönelik çalışmalar yapmaları önerilmektedir.

\section{Kaynakça}

Affolter, R. (2020). Building capacity for academically productive talk: The development of teacher leaders in science professional development (Unpublished doctoral dissertation). University of Massachusetts Amherst.

Akar, Ü. (2007). Öğretmen adaylarmmn bilimsel süreç becerileri ve eleştirel düşünme beceri düzeyleri arasındaki iliş̧ki (Yayımlanmamış yüksek lisans tezi). Afyon Kocatepe Üniversitesi Sosyal Bilimler Enstitüsü, Afyonkarahisar.

Akbıyı, C. \& Seferoğlu, S. S. (2006). Eleştirel düşünme eğilimleri ve akademik başarı. Çukurova

Andolina, M. (2002). Practical guide to critical thinking. Ed. Albany, NY: Delmar/Thomson Learning.Üniversitesi Ĕ̆itim Fakültesi Dergisi, 3(32), 90-99.

Aybek, B. (2007). Konu ve beceri temelli eleştirel düşünme öğretiminin öğretmen adaylarının eleştirel düşünme eğilimi ve düzeyine etkisi. Çukurova Üniversitesi Sosyal Bilimler Enstitüsü Dergisi, 16(2), 43-60.

Aydede, M. N. \& Kesercioğlu, T. (2010). Aktif öğrenme uygulamalarının öğrencilerin eleştirel düşünme becerilerine etkisi. Dokuz Eylül Üniversitesi Buca Ĕ̆itim Fakültesi Dergisi, 27, 14-22.

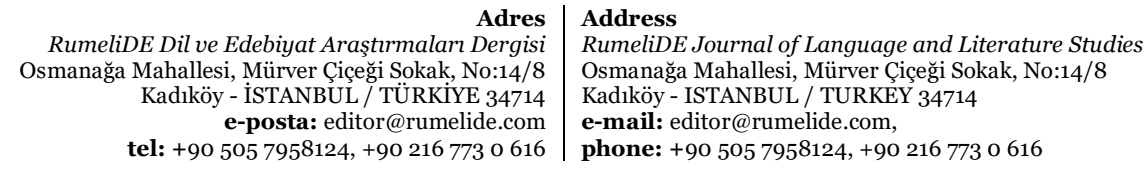


Bağcı, H. \& Şahbaz, N. (2012). Türkçe öğretmeni adaylarının eleştirel düşünme becerileri üzerine bir değerlendirme. Mersin Üniversitesi Ĕ̆itim Fakültesi Dergisi, 8(1), 1-12.

Balta, E. E. (2011). Waldmann modeli ile yapılan metin öğretiminin 8. sinıf öğrencilerinin okuduğunu anlama, eleştirel düşünme ve yaratıcı düşünme becerilerine etkisinin incelenmesi (Yayımlanmamış doktora tezi). Fırat Üniversitesi Eğitim Bilimleri Enstitüsü, Elazı̆̆.

Bayındır, G. (2015). Critical thinking dispositions of primary school secondary stage students (Yayımlanmamış yüksek lisans tezi). Ahi Evran Üniversitesi Sosyal Bilimler Enstitüsü, Kırşehir.

Bulut, A. (2018). 7. sınıf Türkçe dersinde uygulanan aktif öğrenme modelinin öğrencilerin eleştirel düşünme eğilimleri üzerindeki etkileri (Yayımlanmamış doktora tezi). Gaziosmanpaşa Üniversitesi Eğitim Bilimleri Enstitüsü, Tokat.

Can, Ş. \& Kaymakçı, G. (2015). Öğretmen adaylarının eleştirel düşünme eğilimleri. Education Sciences, $10(2), 66-83$.

Creswell, J. W. (2017). Araştırma deseni: Nitel, nicel ve karma yöntem yaklaşımları (Research design: Qualitative, quantitative and mixed methods approaches), (S.B. Demir, çev.). Ankara: Eğiten Kitap.

Cüceloğlu, D. (1999). İyi düşün doğru karar ver. İstanbul: Sistem.

Demir, R. \& Aybek, B. (2014). Lise öğrencilerinin eleştirel düşünme eğilimlerinin çeşitli değişkenler açısından incelenmesi. Muğla Üniversitesi Sosyal Bilimler Enstitüsü Dergisi, 32, 122-140.

Durukan, E. \& Maden, S. (2010). Türkçe öğretmeni adaylarının eleştirel düşünme eğilimleri üzerine bir araştırma. Dumlupınar Üniversitesi Sosyal Bilimler Dergisi, 28, 25-34.

Emir, S. (2012). Eğitim fakültesi öğrencilerinin eleştirel düşünme eğilimleri. Hasan Ali Yücel Eğitim Fakültesi Dergisi, 9(1), 34-57.

Ersoy, E. \& Başer, N. (2012). İlköğretim ikinci kademe öğrencilerinin eleştirel düşünme eğilimleri. Ĕ̆itim ve Öğretim Araştırmaları Dergisi, 1(3), 113-122.

Evren, B. (2012). Fen ve Teknoloji öğretiminde sorgulayıcı öğrenme yaklaşımını öğrencilerin sahip oldukları eleştirel düşünme eğilim düzeylerine ve fen ve teknoloji dersine yönelik tutumlarma etkisi (Yayımlanmamış yüksek lisans tezi). Adnan Menderes Üniversitesi, Aydın.

Fisher, R. (2005). Teaching children to think. Cheltenham, UK: Nelson Thornes.

Furat, Ela (2009). Performans görevlerinin öğrencilerin fen ve teknoloji dersine ilişkin tutumlarna ve eleştirel düşünme eğilimlerine etkisi (Yayınlanmamış yüksek lisans tezi). Ankara Üniversitesi Eğitim Bilimleri Enstitüsü, Ankara.

George, D. \& Mallery, P. (2019). IBM SPSS statistics 26 step by step: A simple guide and reference. Routledge.

Giancarlo, C. A. \& Facione, P. A. (2001). A look across four years at the disposition toward critical thinking among undergraduate students. The Journal of General Education, 5O(1), 29-55.

Howell, P. B., Thomas, S. \& Ardasheva, Y. (2011). Talk in the classroom: Meeting the developmental, cultural, and academic needs of middle school students. Middle Grades Research Journal, 6(1), 47-63.

Iliman Püsküllüoğlu, E. \& Altınkurt, Y. (2018). Öğretmenlerin eleştirel düşünme eğilimleri ile örgütsel muhalefet davranışları arasındaki ilişki. Hacettepe Üniversitesi Ĕ̆itim Fakültesi Dergisi, 33(4), 897-914.

Korkmaz, Ö. (2009). Öğretmenlerin eleştirel düşünme eğilim ve düzeyleri. Ahi Evran Üniversitesi Kirşehir Eğitim Fakültesi Dergisi, 1O(1), 1-13.

Korkmaz, Ö. \& Yeşil, R. (2009). Öğretim kademelerine göre öğrencilerin eleştirel düşünme düzeyleri. Ahi Evran Üniversitesi Kirşehir Ĕ̆itim Fakültesi Dergisi, 1O(2), 19-28.

Köksal, N. \& Çöğmen, S. (2018). Ortaokul öğrencilerinin eleştirel düşünme ve iletişim becerileri. Pamukkale Üniversitesi Eğitim Fakültesi Dergisi, 44, 278-296.

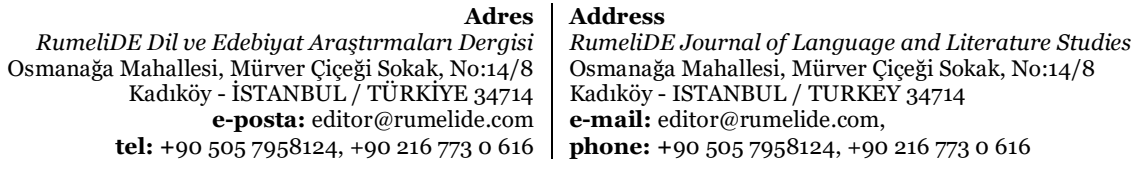


Kurga, H. (2021). Sekizinci sımı öğrencilerinin eleştirel düşünme eğilimlerinin bazı değişkenler açısından incelenmesi (Yayımlanmamış yüksek lisans tezi). Cumhuriyet Üniversitesi Eğitim Bilimleri Enstitüsü, Sivas.

Mete, G. (2021). Ortaokul öğrencilerinin eleştirel düşünme becerilerinin incelenmesi. Ana Dili Ĕ̆itimi Dergisi, 9(2), 492-509.

Michaels, S., O’Connor, M. C., Hall, M. W. \& Resnick, L. B. (2010). Accountable talk sourcebook: For classroom conversation that works. Pittsburgh: University of Pittsburgh Institute for Learning.

Ocak, İ. \& Kutlu Kalender, M. D. (2017). 6. sınıf öğrencilerinin eleştirel düşünme becerilerinin çeşitli değişkenler açısından incelenmesi (Kütahya ili örneği). Kastamonu Üniversitesi Kastamonu Ĕ̈itim Dergisi, 25(4), 1587-1600.

Özcan, Z. Ç. (2017). Ortaokul öğrencilerinin eleştirel düşünme becerilerinin matematik başarısı, yaş ve sınıf seviyesi açısından incelenmesi. Medeniyet Eğitim Araştırmaları Dergisi, 1(1), 43-52.

Özçetin, K. (2019). Akademik tartışma modelinin Türkçe derslerinde kullanlabilirliği üzerine bir durum araştırması (Yayınlanmamış doktora tezi). Marmara Üniversitesi, İstanbul.

Özdemir, H. F. (2006). Kaliforniya Zihinsel Güdülenme Ölçeği’nin uyarlanması (Yayımlanmamış yüksek lisans tezi). Ankara Üniversitesi Ĕ̆itim Bilimleri Enstitüsü, Ankara.

Özdemir, S. M. (2005). Üniversite öğrencilerinin eleştirel düşünme becerilerinin çeşitli değişkenler açısından değerlendirilmesi. Türk Eğitim Bilimleri Dergisi, 3(3), 297-316.

Özden, Y. (2006). Öğrenme ve öğretme. Ankara: Pegem Akademi.

Polat, M. (2017). Sinıf öğretmenlerinin eleştirel düşünme eğilimleri ile yaratıcılk düzeylerinin bazı değişkenlere göre incelenmesi (Yayımlanmamış yüksek lisans tezi). Adıyaman Üniversitesi Sosyal Bilimler Enstitüsü, Adıyaman.

Yıldırım, H. İ. \& Şensoy, Ö. (2011). İlköğretim 7. sınıf öğrencilerinin eleştirel düşünme eğilimi üzerine eleştirel düşünme becerilerini temel alan fen öğretiminin etkisi. Kastamonu Ĕ̆itim Dergisi, 19(2), 523-540.

Yıldırım, R. (2003). Yaratıcllk ve yenilik. İstanbul: Sistem.

RumeliDE Dil ve Edebiyat Araştırmaları Dergisi Osmanağa Mahallesi, Mürver Çiçeği Sokak, No:14/8 Kadıköy - İSTANBUL / TÜRKIYE 34714 e-posta: editor@rumelide.com tel: +90 $5057958124,+902167730616$
Address

RumeliDE Journal of Language and Literature Studies Osmanağa Mahallesi, Mürver Çiçeği Sokak, No:14/8

Kadıköy - ISTANBUL / TURKEY 34714

e-mail: editor@rumelide.com,

phone: +90 5057958124, +90 2167730616 